\title{
PERBANDINGAN JENIS KELAMIN DAN DIMORFISME SEKSUAL PADA PERTUMBUHAN IKAN GURAMI (Osphronemus goramy) SERTA IMPLIKASINYA TERHADAP STRATEGI SELEKSINYA
}

\author{
Sularto", Rita Febrianti, dan Suharyanto
}

Balai Penelitian Pemuliaan Ikan

\begin{abstract}
ABSTRAK
Ikan gurami (Osphronemus goramy Lac.) pada ukuran dewasa memiliki bentuk morfometrik yang khas khususnya pada ikan jantan, sehingga dapat dibedakan antara ikan jantan dan betina. Ikan gurami jantan memiliki dahi menonjol dan bibir tebal. Penelitian ini bertujuan untuk mengevaluasi rasio kelamin dan perbedaan performa pertumbuhan antara jantan dan betina. Ikan uji yang digunakan adalah empat populasi ikan gurami yang berbeda yaitu: Kalimantan Selatan, Jambi, Majalengka, dan Tasikmalaya. Penelitian dilaksanakan di Balai Penelitian Pemuliaan Ikan (BPPI), Sukamandi pada bulan Juni 2014 sampai dengan bulan Juli 2015. Hewan uji yang digunakan adalah benih ikan gurami keturunan galur murni berasal dari Kalimantan Selatan, Jambi (strain Batanghari), Majalengka, dan Tasikmalaya. Perawatan telur, pemeliharaan benih, dan pembesaran menggunakan prosedur operasional standar BPPI tentang pemeliharaan ikan gurami. Pemeliharaan ikan gurami dilakukan selama 14 bulan. Hasil penelitian menunjukkan bahwa berdasarkan jenis kelaminnya jumlah ikan gurami betina $(67,3 \% 80,7 \%$ lebih banyak dibandingkan dengan jumlah jantannya $(19,3 \%$ $32,7 \%$. Setelah mencapai ukuran $>300 \mathrm{~g}$ terdapat perbedaan pertumbuhan antara ikan jantan dan betina $(P<0,05)$ yakni jantan tumbuh lebih cepat dibandingkan betina pada semua populasi yakni berkisar antara 4,74\%5,67\% untuk karakter panjang standar, dan 14,10\%16,52\% untuk karakter bobot. Hal tersebut menunjukkan bahwa ikan gurami memiliki dimorfisme pertumbuhan. Oleh karena itu, ketika dilakukan seleksi berdasarkan pertumbuhan 10\%terbaik didapatkan ikan jantan 55\%80\%lebih banyak dibandingkan ikan betina $(20 \% 45 \%$.
\end{abstract}

\section{KATA KUNCl: dimorfisme; ikan gurami; perbandingan jenis kelamin}

ABSTRACT: Sex ratio and sexual dimorphism in growth of giant gourami (Osphronemus goramy) and its implication for selective breeding strategy. By: Sularto, Rita Febrianti, and Suharyanto

Adult size of giant gouramy (Osphronemus goramy, Lac.) has a distinctive shape of morphometric particularly in male fish, making it easy to distinguish between male and female fishes. Giant gouramy males havea prominent forehead and thick lips. This study aimed to determine sex ratios and differences in growth performancebetween males and females. This study used 4 progenies of giant gouramy seed from four different populations, namely: Kalimantan, Jambi, Majalengka, and Tasikmalaya, aged 14 months. Eggs incubations,seed maintenance and grow-out were conducted using Standard Operational Procedures of Research Institute for Fish Breeding (RIFB) about the rearing of giant gouramy. Seed rearing were carried out for 14 months. The results showed that, based upon the sex ratio, the number of female was more than the number of males, contituting females $67.3 \%-80.7 \%$ and males from $19.3 \%$ to $32.7 \%$ of populations. After reaching thesize of $>300 \mathrm{~g}$ therewere a significant difference in growth between males and females $(P<0.05)$, in which males grew faster than females in all populations between $4.74 \% 5.67 \%$ for the standard length and $14.10 \%-16.52 \%$ for the weight characters. IThis result indicated that giant gouramy have growth dimorphism. Ther efore, when the selection conducted based on the best growth of top $10 \%$ it was found that the number of male composing $55 \% 80 \%$ was higher than the number of female which only accounted for $20 \% 45 \%$

KEYWORDS: dimorphism; giant gourami; sex ratio

\footnotetext{
\# Korespondensi: Balai Penelitian Pemuliaan Ikan. Jl. Raya 2 Pantura Sukamandi, Subang 41263, Jawa Barat, Indonesia. Tel. + (0260) 520500

E-mail: sulart061@ yahoo.com
} 


\section{PENDAHULUAN}

Ikan gurami (Osphronemus goramy Lac.) merupakan ikan asli Indonesia yang mempunyai nilai ekonomis tinggi. Ikan ini banyak tersebar di perairan Jawa, Sumatera, dan Kalimantan.

Pada proses budidaya ikan gurami, saat menjelang dewasa kelamin yakni sekitar ukuran $500 \mathrm{~g}$ ikan gurami jantan memperlihatkan perubahan morfometrik yakni berupa tonjolan pada dahi, serta bibir yang tebal. Selain itu, juga ikan jantan memperlihatkan perilaku seksual dengan membengkokkan badannya ketika dipegang dan diberikan sedikit getaran, hal tersebut dapat dijadikan salah satu cara untuk membedakan antara jantan dan betina pada ikan gurami (Febrianti et al., 2016).

Hu"ssy et al. (2012) menyatakan bahwa dimorfisme seksual dalam ukuran adalah fitur yang terjadi di semua taksa dari mulai krustasea sampai ke mamalia. Dimorfisme ini muncul sebagai konsekuensi dari perbedaan dalam pola pematangan, pola pertumbuhan, ukuran simtotik antar jenis kelamin (Stamps, 1993; Cervino, 2014). Selanjutnya dilaporkan bahwa analisis rasio jenis kelamin menunjukkan bahwa diferensiasi dalam ukuran dimulai setelah pematangan. Herler et al. (2010) dimorfisme seksual adalah fenomena yang terjadi pada beberapa taksa hewan. Seleksi seksual biasanya terjadi pada ikan jantan, yakni ketika betina menunjukkan asortatif kawin atau ketika terjadi kompetisi pasangan. Lind et al. (2015) melaporkan bahwa pada ikan nila perbedaan pertumbuhan individu karena jenis kelamin memiliki konsekuensi penting untuk reproduksi, yakni ikan jantan yang rata-rata lebih besar dari betina. Karena superioritas pertumbuhan pada ikan jantan, maka teknik sex-reversal $100 \%$ jantan merupakan salah satu cara untuk meningkatkan produktivitas dan kontrol reproduksi. Meskipun menurut Kamaruzzaman et al. (2009), dengan adanya ukuran seksual dimorfisme (SSD) ternyata dalam budidaya ikan nila pada po pulasi mono-seks tidak selalu unggul dibandingkan kelamin campuran. Berbeda dengan yang dilaporkan Hu"ssy et al. (2012) bahwa boarfish (Capros aper) adalah spesies berumur panjang terjadi seksual dimorfisme dengan betina mencapai panjang total lebih besar daripada jantan. Penelitian tersebut juga menunjukkan pola pematangan yang khas dal am kaitannya dengan ukuran dan jenis kelamin, serta tingkat pertumbuhan dimorfik setelah pematangan, yakni betina tumbuh lebih cepat daripada jantan.

Pengamatan pertumbuhan pada ikan gurami selama ini ada indikasi perbedaan pertumbuhan antara jantan dan betina (Handajani, 2007). Oleh karena itu, perlu pengamatan yang seksama berkaitan dengan perbedaan pertumbuhan antara jantan dan betina kaitannya strategi proses seleksi. Penelitian ini bertujuan untuk mengevaluasi seks rasio dan perbedaan performa pertumbuhan antara jantan dan betina pada ikan gurami.

\section{BAHAN DAN METODE}

Penelitian dilaksanakan di Balai Penelitian Pemuliaan Ikan (BPPI) Sukamandi pada bulan Juni 2014 sampai dengan bulan Juli 2015. Wadah penelitian yang digunakan yaitu: untuk pemijahan berupa kolam tanah berukuran $20 \mathrm{~m}^{2}$. Hewan uji yang digunakan adalah benih ikan gurami keturunan dari populasi ikan gurami yang berasal dari Kalimantan Selatan (K), Jambi (strain Batang hari) (J), Majalengka (M), dan Tasikmalaya (T).

Perawatan telur dan pemeliharaan benih sampai pembesaran menggunakan prosedur sesuai SOP BPPI tentang pemeliharaan ikan gurami. Pemeliharaan dilakukan selama 14 bulan.

Telur hasil pemijahan dimasukkan ke dalam baskom plastik untuk ditetaskan dengan kepadatan 75 butir/L. Setelah kuning telur habis berumur tujuh hari, larva ikan dipindahkan ke akuarium yang berukuran panjang $100 \mathrm{~cm} \times$ lebar $60 \mathrm{~cm}$, dan tinggi $12,5 \mathrm{~cm}$ dengan kepadatan 80 ekor/L selama satu minggu. Pakan yang digunakan setelah tujuh hari adalah pakan alami yakni cacing sutera (Tubifex) secara ad libitum selama tujuh hari.

Benih yang telah berumur dua minggu dipindahkan ke kolam beton berukuran $25 \mathrm{~m}^{2}$ dengan kepadatan $100 \mathrm{ekor} / \mathrm{m}$. Pakan benih gurami berupa pakan buatan komersial berbentuk tepung (kadar protein minimal $40 \%$ dengan feeding rate (FR) $20 \%$ per hari diberikan selama dua minggu, dilanjutkan dengan pakan berbentuk pelet berukuran 0,7-1 mm (kadar protein 39\%41\% dengan FR 15\% diberikan selama empat minggu. Setelah itu, dilanjutkan dengan pakan berbentuk pelet berkadar protein 31\%33\%dengan FR $10 \%$ diberikan dua kali sehari. Setelah benih berumur dua bulan, selain diberi pakan pelet mulai diberi pakan hijauan berupa daun sente sebanyak $2 \%$

Setelah benih berumur tiga bulan atau berukuran sekitar 5-10 g dipindahkan ke kolam tanah berukuran $400 \mathrm{~m}^{2}$ dengan kedalaman air 80-100 cm yang disekat dengan waring menjadi 12 sekat dengan kepadatan $30 \mathrm{ekor} / \mathrm{m}^{2}$. Pakan yang diberikan berupa pelet apung komersial berkadar protein 31\%33\%sebanyak 3\%dan daun sente $2 \%$ Setelah benih berumur tujuh bulan atau berukuran sekitar 75-100 g dilakukan penjarangan dengan kepadatan $10 \mathrm{ekor} / \mathrm{m}^{2}$, selanjutnya ikan dipelihara sampai berumur 14 bulan.

Parameter pertumbuhan yang diukur berupa panjang $(\mathrm{cm})$ dan bobot $(\mathrm{g})$, masing-masing populasi 
yang diukur sebanyak 175-180 ekor. Seleksi dilakukan berdasarkan karakter bobot individu. Data pertumbuhan panjang dan bobot dianalisis menggunakan program SAS.

\section{HASIL DAN BAHASAN}

Berdasarkan hasil pengamatan pada keturunan empat strain ikan gurami (Tasikmalaya, Majalengka, Jambi, dan Kalimantan) yang berumur 14 bulan didapatkan data rasio kelamin (Gambar 1), dimorfisme pertumbuhan panjang dan bobot (Tabel 1), serta perubahan perbandingan jenis kelamin berdasarkan seleksi pertumbuhan bobot (Tabel 2).

Berdasarkan Gambar 1 terlihat bahwa perbandingan jenis kelamin dari keempat populasi ikan gurami menunjukkan bahwa jumlah populasi ikan gurami betina jauh lebih banyak dibandingan ikan jantannya, yaitu $67,3 \% 80,7 \%$ betina dan $19,3 \% 32,7 \%$ jantan. Analisis statistik menunjukkan perbedaan sangat nyata $(P<0,01)$, strain Jambi menunjukkan proporsi betina terbanyak $(80,7 \%)$ diikuti strain Kalimantan $(68,8 \%$, Majalengka (63,6\%), dan Tasikmalaya $(62,8 \%)$.

Berdasarkan Tabel 1 terlihat adanya perbedaan pertumbuhan antara jantan dan betina (dimorfisme) pada semua populasi. Perbedaan pertumbuhan antara jantan betina terjadi setelah ikan mencapai ukuran $>300 \mathrm{~g}$. Pertumbuhan ikan jantan lebih cepat dibandingkan betina pada semua populasi yakni berkisar antara 4,74\%5,67\% untuk karakter panjang standar, dan 14,10\%16,52\% untuk karakter bobot (Tabel 1). Berdasarkan analisis varian baik panjang maupun bobot antara jantan dan betina terdapat perbedaan yang nyata $(P<0,05)$. Seperti halnya dilaporkan oleh Lin \& Tzeng (2010) bahwa ikan tuna (Thunnus maccoyii) jantan tumbuh lebih besar dibandingkan ikan betinanya. Demikian pula dilaporkan Chakraborty \& Banerjee (2010) bahwa ikan nila jantan tumbuh lebih cepat dibandingkan ikan betina. Hal yang serupa terjadi pada ikan nila seperti dilaporkan oleh Schreiber et al. (1998) bahwa pengaruh interaksi sosial antara jantan dan betina pada ikan nila juga dapat memengaruhi tingkat dimorfisme ukuran. Ikan nila betina tumbuh secara signifikan lebih besar $(P<0,05)$ dibandingkan jantan ketika dipelihara secara terpisah. Namun bila dipelihara secara campuran ternyata betina tumbuh lebih lambat dibandingkan jantan, hal ini disebabkan oleh faktor perilaku lebih dari faktor fisiologis. Menurut Pyron (1996), ukuran seksual dimorfisme sebagian besar merupakan fungsi dari sistem perkawinan, bahwa ikan jantan lebih besar daripada ikan betina, hal ini terjadi dalam sistem perkawinan/pemijahan di mana ikan jantan kawin dengan banyak betina. Secara umum telah diterapkan di masyarakat pembudidaya ikan gurami bahwa rasio perkawinan ikan gurami antara jantan dan betina adalah: satu jantan berbanding $\geq 2$ betina. Ikan gurami jantan mempunyai wilayah teritorial dalam melakukan

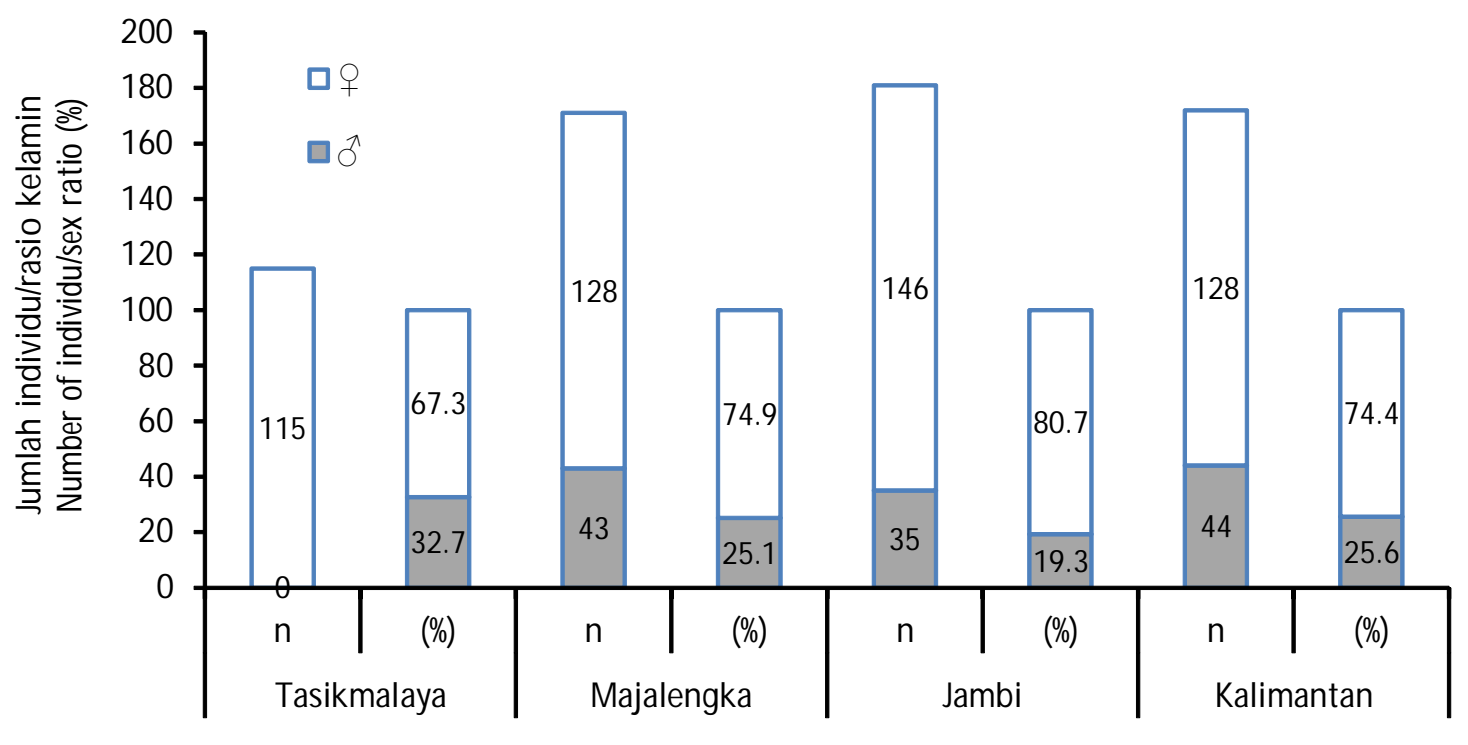

Populasi (Population)

Gambar 1. Perbandingan jumlah dan rasio jenis kelamin empat populasi ikan gurami

Figure 1. Comparison of the number and the sex ratio of four populations of giant gouramy 
Tabel 1. Dimorfisme pertumbuhan panjang standar dan bobot empat populasi ikan gurami Table 1. Sexual dimorphism of standard length and body weight of four populations giant gouramy

\begin{tabular}{|c|c|c|c|c|c|c|c|c|}
\hline \multirow{2}{*}{$\begin{array}{l}\text { Populasi } \\
\text { Population }\end{array}$} & \multicolumn{3}{|c|}{$\begin{array}{c}\text { Panjang standar } \\
\text { Standard length }(\mathbf{c m})\end{array}$} & \multicolumn{3}{|c|}{$\begin{array}{l}\text { Bobot badan } \\
\text { Body weight (g) }\end{array}$} & \multicolumn{2}{|c|}{$\begin{array}{c}\text { Perbandingan jenis kelamin } \\
\text { Sex ratio }(\%)\end{array}$} \\
\hline & q & $0^{\pi}$ & $\begin{array}{c}\text { Dimorfisme } \\
\text { Dimorphism (\%) }\end{array}$ & q & $0^{\pi}$ & $\begin{array}{c}\text { Dimorfisme } \\
\text { Dimorphism (\%) }\end{array}$ & 우 & 0 \\
\hline KK & 25.19 & 26.38 & 4.74 & 585.86 & 668.46 & 14.10 & 68.75 & 31.25 \\
\hline J & 22.49 & 23.55 & 4.69 & 406.20 & 466.54 & 14.85 & 82.61 & 17.39 \\
\hline MM & 24.65 & 25.79 & 4.63 & 538.64 & 616.89 & 14.53 & 63.56 & 36.44 \\
\hline TT & 23.97 & 25.33 & 5.67 & 512.55 & 597.21 & 16.52 & 62.83 & 37.17 \\
\hline
\end{tabular}

Tabel 2. Perbandingan jenis kelamin berdasarkan proporsi terseleksi pada bobot ikan gurami berumur 14 bulan

Table 2. Sex ratio base on selected proportions of weight of giant gouramy 14 months old

\begin{tabular}{|c|c|c|c|c|c|c|c|c|}
\hline \multirow{3}{*}{$\begin{array}{l}\text { Proporsi } \\
\text { terseleksi } \\
\text { Selected } \\
\text { proportions } \\
\text { (\%) }\end{array}$} & \multicolumn{8}{|c|}{$\begin{array}{l}\text { Perbandingan jenis kelamin empat populasi ikan gurami } \\
\text { Sex ratio of four populations of giant gourami ( } \% \text { ) }\end{array}$} \\
\hline & \multicolumn{2}{|c|}{ Tasik } & \multicolumn{2}{|c|}{ Majalengka } & \multicolumn{2}{|c|}{ Jambi } & \multicolumn{2}{|c|}{ Kalimantan } \\
\hline & 우 & $\sigma^{\lambda}$ & 우 & $\hat{0}$ & 우 & $\hat{0}$ & q & $\widehat{0}$ \\
\hline 100 & 67.30 & 32.70 & 74.90 & 25.10 & 80.70 & 19.30 & 74.40 & 25.60 \\
\hline 30 & 51.67 & 48.33 & 60.00 & 40.00 & 73.33 & 26.67 & 60.00 & 40.00 \\
\hline 15 & 36.67 & 63.33 & 43.33 & 56.67 & 60.00 & 40.00 & 50.00 & 50.00 \\
\hline 10 & 20.00 & 80.00 & 25.00 & 75.00 & 35.00 & 65.00 & 45.00 & 55.00 \\
\hline
\end{tabular}

perkawinannya. Menurut Heske \& Ostfeld (1990), ikan jantan biasanya lebih besar daripada betina pada spesies di mana jantan menjaga wilayah teritorial. Dari hasil pengamatan dan pengalaman para pembudidaya bahwa pada ikan gurami sering terjadi pertarungan antar jantan bila wilayah pemijahannya terganggu oleh jantan lainnya, hal tersebut menunjukkan bahwa ikan gurami jantan memiliki daerah teritorial.

Berdasarkan Tabel 2 terlihat perubahan persentase rasio atau perbandingan jenis kelamin. Dengan meningkatnya intensitas seleksi ternyata rasio jantan semakin meningkat dan sebaliknya rasio betina semakin sedikit. Apabila dikaitkan dengan target seleksi pada ikan gurami, di mana diperlukan individu/ induk betina minimal dua kali induk jantan. Oleh karena itu, dalam pelaksanaan proses seleksi ikan gurami diperlukan strategi seleksi agar kegiatan seleksi dapat efektif dan efisien. Untuk melakukan seleksi harus memperhatikan faktor sarana dan biaya. Bila seleksi dilakukan sekaligus pada ukuran besar/dewasa, maka akan memerlukan biaya yang besar terutama biaya pakan. Sebaliknya apa bila seleksi dilakukan pada ukuran terlampau kecil dikhawatirkan akan kehilangan gen yang mempunyai potensi baik atau mendapatkan rasio kelamin yang tidak sesuai dengan yang diharapkan. Dengan melihat pola perubahan pertumbuhan berdasarkan seksual dimorfisme pada karakter bobot, seleksi ikan gurami sebaiknya memperhatikan jenis kelamin, di mana perlu sedini mungkin memisahkan jenis kelaminnya. Oleh karena itu, untuk tujuan efisiensi seleksi ikan gurami perlu dilakukan dua tahapan seleksi yakni seleksi pertumbuhan sebelum dewasa kelamin yaitu sekitar $300 \mathrm{~g}$, selanjutnya dilakukan seleksi pertumbuhan setelah terjadi dewasa kelamin. Berdasarkan penelitian ini, ikan gurami pada ukuran di bawah $300 \mathrm{~g}$ belum memperlihatkan perilaku seksual atau dengan kata lain belum dewasa kelamin, sedangkan setelah berukuran mulai $\geq 300$ g mulai memperlihatkan perilaku seksual dan diikuti dengan perubahan morfometrik. Ikan gurami jantan pada ukuran tersebut bila dipegang dengan diberi sedikit rangsangan atau getaran, maka akan merespons dengan membengkokkan badannya membentuk setengah lingkaran sambil bergetar 
dengan kuat, sedangkan yang betina tidak memberikan respons yang spesifik. Selain memperlihatkan perilaku seksual, ikan gurami jantan dengan bertambahnya umur dan ukuran terjadi perubahan morfometrik berupa tonjolan pada dahi dan bibir bawah lebih tebal dibandingkan betina (Febrianti et al., 2016;. Seperti dilaporkan oleh Purdom (1993) ada beberapa kelompok ikan seperti halnya beberapa dari cichlid bahwa ikan jantan memiliki ukuran lebih dominan dan seringkali memperlihatkan perilaku seksual positif seperti membuat sarang dan merawat telur.

Dari Tabel 3 tersebut menunjukkan bahwa ikan gurami jantan setelah mencapai dewasa, kelamin tumbuh lebih cepat dibanding betinanya. Tabel 2 dan
Tabel 3 merupakan contoh hasil simulasi bila seleksi dari populasi ikan gurami dilakukan pada umur 14 bulan berdasarkan karakter bobot tanpa memisahkan jenis kelamin. Fenomena yang terjadi pada ikan gurami seperti contoh pada Tabel 3 tersebut perlu dicermati kaitannya dengan proses seleksi maupun budidaya. Beradasarkan hasil seleksi tersebut, maka akan didapatkan jantan lebih banyak dibanding betinanya, sedangkan proses pemijahan ikan gurami diperlukan betina lebih banyak dibanding jantan. Dengan demikian maka proses seleksi tidak sesuai target yang diinginkan. Hal tersebut akan mengdapatkan hasil seleksi yang tidak efisien. Oleh karena itu, untuk melakukan seleksi pada ikan gurami perlu strategi khusus agar didapatkan hasil seleksi sesuai yang diinginkan, serta efisien. Kegiatan seleksi sebaiknya

Tabel 3. Proporsi pertumbuhan jantan dan betina berdasarkan karakter 10\%terbaik pada ikan gurami berumur 14 bulan

Table 3. The growth of the weight proportion of males and females based on the top $10 \%$ of the population of giant goramy at 14 month old

\begin{tabular}{|c|c|c|c|c|c|c|c|c|}
\hline \multirow[b]{2}{*}{ No. } & \multicolumn{2}{|c|}{ Tasikmalaya } & \multicolumn{2}{|c|}{ Majalengka } & \multicolumn{2}{|c|}{ Jambi } & \multicolumn{2}{|c|}{ Kalimantan } \\
\hline & $\begin{array}{l}\text { Bobot } \\
\text { badan } \\
\text { Body } \\
\text { weight (g) }\end{array}$ & $\begin{array}{c}\text { Jenis } \\
\text { kelamin } \\
\text { Sex }\end{array}$ & $\begin{array}{l}\text { Bobot } \\
\text { badan } \\
\text { Body } \\
\text { weight (g) }\end{array}$ & $\begin{array}{l}\text { Jenis } \\
\text { kelamin } \\
\text { Sex }\end{array}$ & $\begin{array}{l}\text { Bobot } \\
\text { badan } \\
\text { Body } \\
\text { weight (g) }\end{array}$ & $\begin{array}{c}\text { Jenis } \\
\text { kelamin } \\
\text { Sex }\end{array}$ & $\begin{array}{l}\text { Bobot } \\
\text { badan } \\
\text { Body } \\
\text { weight (g) }\end{array}$ & $\begin{array}{c}\text { Jenis } \\
\text { kelamin } \\
\text { Sex }\end{array}$ \\
\hline 1 & 725 & M & 763 & M & 782 & M & 897 & M \\
\hline 2 & 699 & $M$ & 752 & $M$ & 690 & M & 842 & $M$ \\
\hline 3 & 686 & M & 749 & M & 660 & M & 817 & M \\
\hline 4 & 681 & M & 735 & M & 651 & M & 810 & $M$ \\
\hline 5 & 677 & M & 729 & $\mathrm{~F}$ & 638 & M & 788 & $M$ \\
\hline 6 & 674 & $M$ & 721 & $M$ & 633 & $\mathrm{~F}$ & 756 & $\mathrm{~F}$ \\
\hline 7 & 669 & $M$ & 713 & $M$ & 630 & $\mathrm{~F}$ & 747 & $\mathrm{~F}$ \\
\hline 8 & 665 & M & 707 & $M$ & 627 & M & 744 & $\mathrm{~F}$ \\
\hline 9 & 664 & M & 706 & $\mathrm{~F}$ & 622 & M & 726 & M \\
\hline 10 & 659 & $M$ & 686 & M & 621 & $\mathrm{~F}$ & 726 & $\mathrm{~F}$ \\
\hline 11 & 654 & $\mathrm{~F}$ & 677 & M & 601 & M & 720 & M \\
\hline 12 & 654 & $\mathrm{~F}$ & 672 & M & 600 & M & 720 & $\mathrm{~F}$ \\
\hline 13 & 653 & M & 662 & M & 593 & $\mathrm{~F}$ & 716 & M \\
\hline 14 & 652 & M & 658 & $\mathrm{~F}$ & 590 & M & 712 & $\mathrm{~F}$ \\
\hline 15 & 643 & $M$ & 650 & $M$ & 585 & $M$ & 710 & $\mathrm{~F}$ \\
\hline 16 & 642 & $M$ & 644 & $M$ & 584 & $\mathrm{~F}$ & 708 & M \\
\hline 17 & 639 & $\mathrm{~F}$ & 641 & $M$ & 578 & M & 702 & $\mathrm{~F}$ \\
\hline 18 & 637 & M & 639 & $\mathrm{~F}$ & 578 & $\mathrm{~F}$ & 698 & M \\
\hline 19 & 633 & $M$ & 636 & $\mathrm{~F}$ & 575 & M & 690 & $\mathrm{~F}$ \\
\hline 20 & 631 & $\mathrm{~F}$ & 636 & $M$ & 565 & $\mathrm{~F}$ & 690 & $M$ \\
\hline \multirow{2}{*}{$\begin{array}{l}\text { Perbandingan jenis kelamin } \\
\text { Sex ratio }(\%)\end{array}$} & 20 & $F$ & 25 & $\mathrm{~F}$ & 35 & $\mathrm{~F}$ & 45 & $\mathrm{~F}$ \\
\hline & 80 & $M$ & 75 & $M$ & 65 & M & 55 & M \\
\hline $\begin{array}{l}\text { Rata-rata bobot populasi } \\
\text { Average weight of population (g) }\end{array}$ & 520 & & 501 & & 444 & & 490 & \\
\hline
\end{tabular}

Keterangan (Note): $F=$ betina (female); $M=$ jantan (male); $n=175-180$ 
dilakukan secara bertahap. Tahap pertama dilakukan seleksi berdasarkan pertumbuhan sebelum ikan berukuran $300 \mathrm{~g}$. Tahap kedua seleksi dilakukan setelah ikan berukuran $>300 \mathrm{~g}$ dengan cara memisahkan jantan dan betina berdasarkan gabungan antara morfometrik dan perilaku seksual (Febrianti et al., 2016) dan selanjutnya dilakukan seleksi berdasarkan pertumbuhan pada masing-masing jenis kelamin sesuai target jumlah yang diinginkan.

\section{KESIMPULAN}

Perbandingan antara jantan dan betina dalam populasi pada empat strain ikan gurami (Tasikmalaya, Majalengka, Jambi, dan Kalimantan) menunjukkan bahwa populasi betina lebih banyak dibandingkan ikan jantan, yaitu $67,3 \% 80,7 \%$ betina dan $19,3 \% 32,7 \%$ jantan. Setelah mencapai ukuran $>300 \mathrm{~g}$ terjadi dimorfisme seksual pada karakter pertumbuhan, ikan gurami jantan tumbuh lebih cepat dibandingkan ikan gurami betina sebesar $14,1 \% 16,5 \%$ untuk karakter bobot. Hasil simulasi seleksi berdasarkan pertumbuhan bobot $10 \%$ terbaik didapatkan ikan jantan dua kali lebih banyak dibanding ikan betina.

\section{DAFTAR ACUAN}

Cervino, S. (2014). Estimating growth from sex ratio-at-length data in species with sexual size dimorphism. Fisheries Research, 160, 112-119.

Chakraborty, S.B., \& Banerjee, S. (2010). Comparative growth performance of mixed-sex and monosex nile tilapia population in freshwater cage culture system under Indian perspective. International Journal of Biology, 2(1), 44-50.

Febrianti, R., Sularto, \& Suharyanto. (2016). Penentuan awal jenis kelamin ikan gurami (Osphronemus goramy). Prosiding Seminar Masyarakat Ikhtiologi.

Handajani, H. (2007). Perendaman Iarva gurami (Osphronemus gouramy) dengan umur yang berbeda pada hormon metiltestoteron terhadap keberhasilan pembentukan monosex jantan. Jurnal Protein, 5(2), 11-119.

Heske, E.J., \& Ostfeld, R.S. (1990). Sexual dimorphism in size, relative of testes, and mating systems in
North American voles. Journal of Mammalogy, 71(4), 510-519.

Herler, J., Kerschbaumer, M., Mitteroecker, P., Postl, L., \& Sturmbauer, C. (2010). Sexual dimorphism and population divergence in the Lake Tanganyika cichlid fish genus Tropheus. Frontiers in Zoology, 7, 4. http://www.frontiersinzoology.com/content/ $7 / 1 / 4$

Hu"ssy, K., Coad, J.O., Farrell, E.D., Clausen, L.W., and Clarke, MW. (2012). Sexual dimorphism in size, age, maturation, and growth characteristics of boarfish (Capros aper) in the Northeast Atlantic. ICES Journal of Marine Science, 69(10), 1729-1735. doi:10.1093/icesjms/fss156.

Kamaruzzaman, N., Nguyen, N.H., Hamzah, A., \& Ponzoni, R.W. (2009). Growth performance of mixed sex, hormonally sex reversed and progeny of YY male tilapia of the GIFT strain (Oreochromis niloticus). Aquaculture Research, 40(6), 720-728.

Lind, C.E., Safari, A., Agyakwah, S.K., Attipoe, F.Y.K., El-Naggar, G.O., Hamzah, A., Hulata, G., Ibrahim, N.A., Khaw, H.L., Nguyen, N.H., Maluwa, A.O., Zaid, M., Zak, T., \& Ponzoni, R.W. (2015). Differences in sexual size dimorphism among farmed tilapia species and strains undergoing genetic improvement for body weight. Aquaculture Reports, 1, 20-27.

Lin, Y.T., \& Tzeng, W.N. (2010). Sexual dimorphism in the growth rate of southern bluefin tuna (Thunnus maccoyii) in the Indian Ocean. J. Fish. Soc. Taiwan, 37(2), 135-151.

Purdom, C.E. (1993). Genetics and fish breeding. Chapman \& Hall.

Pyron, M. (1996). Sexual size dimorphism and phylogeny in North American minnows. Biological Journal of the Linnean Society, 57, 327-341.

Schreiber, S., Focker, U., \& Becker, K. (1998). Individually reared female nile tilapia (Oreochromis niloticus) can grow faster than males. J. Appl. Ichthyol., 14, 43-47.

Stamps, J.A. (1993). Sexual size dimorphism in species with asymptotic growth after maturity. Biological Journal of Linnean Society, 50(2), 123-145. 